\title{
Mapalus Cultural Reconstruction in Tompaso Baru Village South Minahasa Regency
}

\author{
${ }^{1}$ Meity Najoan* \\ History Education Department \\ Universitas Negeri Manado \\ Tondano, Indonesia \\ meitynajoan@unima.ac.id
}

\author{
${ }^{2}$ Xaverius Erick Lobja \\ Geography Education Department \\ Universitas Negeri Manado \\ Tondano, Indonesia \\ erichlobja@unima.ac.id
}

\author{
${ }^{3}$ Aksilas Dasfordate \\ History Education Department \\ Universitas Negeri Manado \\ Tondano, Indonesia \\ adosfordate@unima.ac.id
}

\begin{abstract}
This study tries to explore how Mapalus values develop in the lives of people in Tompaso Baru. The importance of this research is to preserve Minahasa's cultural customs, especially in terms of Mapalus culture, for the values contained therein remain sustainable and can be passed on by the next generation in shaping the nation's identity and to form a national character that has values Civic culture. The method and approach used are qualitative. Analysis of the data used in this study is qualitative analysis. Based on the results of the study it is known that: (1) Mapalus is a manifestation of the Minahasa people's way of life as a system of rules of life arrangement and empowerment of individuals and ancestral heritage communities who use it as a principle of family life due to a set of behavioral concepts for life and to solve problems. (2) Values contained in Mapalus culture Participatory, wherein Mapalus activities all people are actively involved starting from the beginning of the plan to conduct Mapalus in completion. In every Mapalus activity, all people who participated in the activity we're involved fully from the planning of the activity to the completion of the activity. The value of Solidarity, in Mapalus culture, appears a sense of togetherness, a sense of unity of interest, a sense of sympathy, as one member of the same class to jointly conduct Mapalus activities. Reciprocal values, in Mapalus culture everyone works together, helping one another. Therefore, if someone who conducts Mapalus activities for themselves or their families, then when there is Mapalus activity for other people/families, the person concerned should also repay him to work for the family. Leadership Value, in Mapalus culture the ability of a leader to recognize the time and need to conduct activities, identify, communicate the implementation strategy / Mapalus activities to everyone involved in these activities for these activities can be achieved. Mutual Cooperation values in Mapalus culture doing a work conducted together, helping each other, then enjoy the results of the work together is also the main core of Mapalus culture.
\end{abstract}

Keywords: Mapalus, Culture, Mutual Cooperation, Solidarity, Minahasa

\section{INTRODUCTION}

In the Minahasa community, cooperation culture is usually called as Mapalus culture. Mapalus culture is a system of cooperation for the common interest inherited by Minahasa ancestors based on the philosophy of life of the Minahasa people put forward by Dr. Sam Ratulangi is "si tou timou tumou tou / human life to revive other humans" [1]. Mapalus is a system of cooperation based on helping between several people and the cooperation of some villagers in the public interest, around domestic work, agriculture, death, marriage and community service [2].

Initially Mapalus conducted specifically on activities related to agriculture, ranging from clearing land to picking produce or harvesting. But along with its development also applied in every social activity, such as in traditional ceremonial activities, making boats, marriage, death, building houses and so on. Mapalus, in essence, has the basis and activities of Minahasa people who are called with basic sincerity and deep touching hearts with full awareness and responsibility to make humans and their groups of teaching the mind to live and prosper for each person and group in the community transforming life. Mapalus as a working system has ethos values such as reciprocal ethos, participatory ethos, solidarity, responsibility, cooperation, good leaders, discipline, transparency, equality, and trust (Umbas, 2011).

Mapalus is also known as the local Spirit and local wisdom of the people in Minahasa. Mapalus is an embodiment or manifestation of the Minahasa people's way of life is manifested as a system of rules of life and empowerment of individuals and ancestral heritage uses it as a principle of family life due to it is a set of behavioral concepts for life and for solving common problems, which have been formulated in $\mathrm{Si}$ Tou Timou Tumou Tou. Mapalus, from ma, saling, palus, got a turn (H.M. Taulu). Mapalus, or helping each other, is a system that has existed since time immemorial and comes from the principle of family life, as a legacy of an effort of family unity from the days of our ancestors, but which disappears due to people begin to selfish or other causes (Graafland). Mapalus is an expression of the Minahasa people's way of life which is not just a helping-hand or cooperation [3], [4].

Initially, Mapalus was conducted specifically on activities related to agriculture, from clearing land to harvesting. But along with the development of Mapalus Culture is not only limited in agriculture, but also applied in every social activity, and in almost all fields of life, such as in traditional ceremonial activities, building houses, building boats, marriages, deaths, etc. which of course, this activity is conducted together or cooperation. Mapalus is the basic nature and activities of the life of the Minahasa people who are called by touching sincerity of the basic and deep 
conscience (touching hearts) with full awareness and responsibility to make humans and their groups (teaching mind) mutually and prosperous each person and group in their community (transforming life) [5], [6].

According to the book, The Mapalus Way, Mapalus as a working system has ethos values such as reciprocal ethos, participatory ethos, solidarity, responsibility, cooperation, good leadership, discipline, transparency, equality, and trust. Along with the development of the social organization, functions implement activities with the principle of Mapalus, nowadays, Mapalus is also often used as the principle of a social organization in Minahasa. In its application, Mapalus functions as a deterrent for the world economic recession, a means to motivate and mobilize people for the stabilization of development, and is a means of fostering a productive work spirit for the success of independent operations, for example, agricultural intensification and extensification programs.

The principle of solidarity reflected in Mapalus is reflected in the economy of the community in Minahasa, namely the introduction of the Tamber economic principle. The principle of timber economics refers to an activity to give something to other people, or residents of sewanua (village) voluntarily and for free, without calculating or expecting compensation. The principle of the timber economy is family-based. In terms of traditional motivation, this principle contains a meaning of cultural glue (cultural preservation) which expresses social care, even indicators of social intimacy. The cultural factor of the tamber economic principle is based on the fertile and abundant natural conditions of the Minahasa, and the typical Minahasa people who tend to be diligent and generous. The existence of Mapalus makes the Minahasa community more related to one another regardless of ethnicity, religion, race, and intergroup (SARA).

Therefore as young people, let's keep and preserve the culture inherited from our ancestors. Mapalus culturalhistorical values such as reciprocal ethos, participatory ethos, solidarity, responsibility, cooperation, good leadership, discipline, transparency, equality, and trust. The Minahasa community in general in several aspects can work together and help each other. The culture is still maintained and preserved. In everyday life, we can feel the attitude of like to help and cooperate. Except for some activities which are a series of Mapalus such as using a wind instrument when inviting groups to Mapalus have started to disappear. Slowly authenticity begins to erode with modernization. While in a participatory ethos where one's mental and emotional involvement to the achievement of goals and take responsibility in it. Where people are included in planning and implementation and also bear responsibility according to the level of maturity and level of obligations. The aspect of solidarity is a sense of togetherness, a sense of unity of interest, a sense of sympathy, as one member of the same class. or it can be interpreted feelings or expressions in a group formed by shared interests. Cooperation in doing work together, helping each other, then enjoy the results of the work together as well.

There is also the principle of good leadership, where the ability of a leader to recognize the time and need to make changes, identify the direction of change, communicate change strategies to people in the organization, especially those who support change and empower them to make changes and facilitate efforts to achieve the goals change.

Based on observations made in Tompaso Baru District, South Minahasa Regency, mutual assistance activities or help is known as Mapalus is still be seen. Mapalus cultural construction created in the District of Tompaso Baru, South Minahasa Regency is built on attachment to one another, based on social relations, namely family ties, unity ties, geographical closeness and ties of equality of trust is manifested in community activities. The Mapalus culture has been socially constructed in the community in Tompaso Baru District, South Minahasa Regency has been conducted from generation to generation as one of the original cultural heritages which is a unifying forum for the community, which still receives a positive response from the villagers. who took part or participated in Mapalus.

Mapalus is a culture elaboration philosophy of Si tou Timou Tomou Tou as an activity of community life with the nature of cooperation and has been attached to each of the sons and daughters of the Minahasa community [7], [8]. Mapalus is the basic word palus which among others means to pour and mobilize, so Mapalus implies an attitude and action based on the awareness of the necessity to move by gathering (uniting) the power (strength and intelligence) of each community member to obtain an optimal result according to previously agreed goals [9]. Based on the description, the researcher is interested to know how the construction of Mapalus cultural values formed in the life of the community in Tompaso Baru District, South Minahasa Regency.

According to reference [10] Mapalus etymologically has the following meanings: (a) Mapalus for Tonsea and Toulour people is called Mapalus. Mapalus comes from the word "ma" meaning each other, "palus" which means to pour or give. So thus the word Mapalus means mutual giving or shelter to people in need. (b) Mapalus for the Tombuluus is also called Mapalus. The word Mapalus is a combination of two words "ma" means doing something, "palus" means joint activities and each member in rotation. When we put together the word Mapalus means people are in turn [11]. (c) Mapalus for Tontemboans is called maendo. In the prefix "ma" with the word "endo" which means day or sun. So, maendo means taking the day or using the day to work together with others [9].

While the understanding of the word Mapalus according to [2] is as follows: (1) Mapalus means to work with friends of several people and work alternately. (2) Mapalus is please help based on cooperation to achieve a 
purpose (dedicating in the public interest). (3) Mapalus means please help due to someone has received the support he will provide help.

In general, Mapalus means a form of cooperative assistance to help several people in the same village in the form of a group ranging from 10 to 40 people, members of the group have the same interests that will be associated in turn according to custom reference [12]. The Minahasa custom as mentioned before, in the concept of [13] states custom is an ideal form of culture which is called the code of conduct regulates, controls, and gives direction to human behavior and actions in society. Customs are norms that have been conducted in the life of the community will come into effect as a habit which is a way of behavior in society contains a network, ideals, norms, rules, views, and so on.

In its development Mapalus culture also experienced changes. Changes occur can take place quickly in a short time as well as relatively slow changes. Factors cause change can come from within and from the outside affect the community itself. Reference [14] states there are two factors affect changes that occur in society, namely changes are influenced from within and changes are influenced from outside the community. These changes can cause a shift, reduction or addition to the culture of the community.

Social changes occur are not always beneficial. The community should be able to choose critically and assess what should be changed for progress, and what should be maintained, for no adverse effects arise. Thus, new people should be created capable of mastering broad technical possibilities, who are not confused in the process of social change. Therefore, it can be said the process of social change can be very beneficial if it is successful in changing its people too, which in turn will determine and control the direction of change itself, by first knowing the characteristics of social change.

This study tries to explore how Mapalus values develop in the lives of people in Tompaso Baru. The importance of this research is to preserve Minahasa's cultural customs, especially in terms of Mapalus culture, for the values contained therein remain sustainable and can be passed on by the next generation in shaping the nation's identity and to form a nation has characteristics that have civic culture values.

\section{RESEARCH METHODS}

This study uses a qualitative approach due to it is according to the problems studied, and also (1) the approach in this study is more flexible, (2) can present data directly, the nature of the relationship between informants and researchers, (3) can adjust and be sensitive to what is studied. Therefore, to understand the meaning of naturally occurring phenomena related to the research in this study, the research acts as a key instrument whose task is to go directly to the informant as a source of data. Observation from within or participatory as part of the emic perspective acts as an instrument to understand Maplus culture in the Tompaso Baru community in South Minahasa.
This research is about Mapalus culture in Tompaso Baru Village, South Minahasa Regency. Where this research is to find out how Mapalus cultural values which are still maintained today. The informants in this study are people who know and understand Mapalus cultures such as traditional leaders, community leaders, and government figures. Data collection is done through observation, interviews, and documentation. According to Atkinson \& Hammersley that direct observation is a humanist and impressionative approach (Denzin and Licoln, 1994). This interview process aims to collect field data that cannot be observed which are unclear. This interview data were obtained from sources of information who understand and know deeply about the problem under study. The use of documents in this study, as an effort to obtain research data, aims to obtain written data about Mapalus culture.

Besides written documents such as pictures or photographs taken are needed to show Mapalus culture in the Minahasa community. Analysis of the data used in this study is qualitative analysis. In qualitative research, data analysis has been conducted before researchers enter the field. The analysis is conducted on the results of the preliminary study, or secondary data, which will be used to determine the focus of the study. The focus of this research is temporary and will develop after researchers enter the field. Data analysis in qualitative research is more focused during the process in the field along with data collection. According to reference [15], it was conducted from the time the data collection took place until the data collection was completed within a certain period. Therefore, it is not possible to separate data collection activities from data analysis with one another, both of which take place simultaneously.

\section{Get to Know Mapalus Culture}

\section{RESULT AND DISCUSSION}

Amid the impact of modernization and the strengthening of individualism, the Minahasa community in North Sulawesi still maintains the tradition of togetherness and cooperation known as Mapalus. In practice, Mapalus is an old institutionalized practice in Minahasa since Christianity was largely accepted and since the forced cultivation of coffee came into force in the early 19th century. The word "Mapalus" was formed from two "ma" words as a start to refer to an active process, and "palus "which means" poured out "or" shared" [4].

So it can be concluded Mapalus in terms means to devote each other's energy and resources or to share what each party has. As a work practice, Mapalus means working together or taking turns with agreements that are accepted together to complete work (farming) for the expected goals together. Mapalus has now been transformed in many areas of life, both within extended families, communities or between community groups, in joy and sorrow. The shape has also changed depending on needs.

However, the principle still maintained is togetherness in bearing or doing good things to support the sustainability of life together. In the context of Mapalus cooperation, it seems simple, but it is different from the usual cooperation. 
Mapalus is a value and practice of searching for the meaning of life, which proceeds in the Minahasa people, then institutionalizes in social life. Mapalus later became one of the institutions of Minahasa civilization life. As a value, a person or family that has received a "palus" is obliged to retaliate, both in the form of funds and power with the same value. If it does not do there is a moral sanction. No responsibility or immoral bears. In life will be hated, set aside in social relations [16].

Mapalus is an embodiment or manifestation of the Minahasa people's way of life that is manifested as a system of life management and empowerment of individuals and ancestral heritage people who use it as a principle of family life due to it is a set of behavioral concepts for life and for solving common problems. According to Graafland, Mapalus is a system that has existed since time immemorial and originated from the principle of family life, as a legacy of an effort of family unity from the days of the ancients, but which disappeared due to people began to selfish or other causes. Mapalus is an expression of the Minahasa people's way of life which is not just a helping-hand or cooperation [3].

Initially, Mapalus was conducted specifically on activities related to agriculture, from clearing land to harvesting. But along with the development of Mapalus not only limited to agriculture, but also applied in every social activity, and almost all fields of life, as in other traditional activities, such as marriage, death or establishing a new house and other activities which are done together, or cooperation. Mapalus is essentially the life activity of the Minahasa people who are called with touching sincerity of the conscience and deep touching (touching hearts) with full awareness and responsibility to make humans and their groups (teaching mind) mutually and prosperous each person and group in their community (transforming life).

\section{Participatory Values in Mapalus Culture}

Based on the data analysis, it can be explained as a working system Mapalus has some participatory values. Where in Mapalus activities everyone is actively involved, starting from the beginning of the plan to conduct Mapalus until it is finished. In every Mapalus activity, all people who participated in the activity we're involved fully from the planning of the activity to the completion of the activity. So all those involved in these should take responsibility according to what they are doing. The participation of the Tompaso Baru community in Mapalus activities was very high because the community was very aware of the benefits they gained by participating as Mapalus members.

Especially for example in Mapalus grief. The entire community usually obeys all the existing rules. The rule referred is the obligation of all members every time a mourning event occurs for families who are members of a mourn Mapalus. For example, the rules contained in Mapalus mourning, among others, bring mandatory contributions Rp. 5,000, and 1 Liter of Rice. All the money and rice collected will be handed over to the bereaved family. But the rules vary according to each Mapalus group. Some bring food, coffee, sugar, and others that have been determined.

\section{Value of Solidarity in Mapalus Culture}

As we all know every cultural element in each ethnic group should have value. This value is then pursued by every human being. Every human action is consciously or not always oriented to a certain value. For cultural action has a teleological dimension when the action leads to something that is in front of us and there is an intention to achieve it consequently. One of them is the value of this solidarity. Solidarity becomes a universal value that is shared and pursued together. Not solidarity if this action is conducted alone. Solidarity presupposes an active partner. Here there are other subjects involved to accept the solider's actions. If there are no other subjects, then the action is of no value at all. In the context of the value of solidarity in Mapalus culture a sense of togetherness, a sense of unity of interest, a sense of sympathy, as one of the members of the same class are to conduct Mapalus activities together. In every Mapalus activity conducted, every old, young, female community will gather together in the place that will be conducted Mapalus activities. Communities gather spontaneously to help work according to what is done. The presence of this community is one part of the values of the togetherness of the Minahasa community. In Mapalus activities do not accord at ethnicity, religion, race, and intergroup (SARA).

\section{Reciprocal Values in Mapalus Culture}

Apart from participatory values and solidarity, there are also reciprocal values in Mapalus culture. For sure, Mapalus culture has taken root and entrenched among the Minahasa community, especially in Tompaso Baru, giving rise to reciprocal relations. Mapalus culture is a cooperative activity, helping one another. Therefore, if someone who conducts Mapalus activities for themselves or their families, then when there is Mapalus activity for other people/families, the person concerned should repay him to work for the family.

If anyone does not fulfill their obligations as a member of the Mapalus work, they will be sanctioned according to the policies of the Mapalus chairperson agreed by their members. Examples of sanctions are given if a member cannot attend without a clear reason usually the person is excluded from the community, not included in Mapalus activities in other groups due to they are considered unable to pay for it.

\section{The Value of Leadership in Mapalus Culture}

Socio-psychologically, Mapalus culture has great potential as a driver of regional development in Minahasa, especially in Tompaso Baru. In Mapalus the ability of a leader to recognize the time and need to conduct activities, 
identify, communicate the implementation strategy / Mapalus activities to everyone involved in the activity can be achieved. Mapalus is an activity that helps and improves community unity and welfare, so rules in Mapalus work such as clearing fields/gardens, everyone who participates in Mapalus is obliged to attend scheduled agricultural work activities, for example working from 7 am to 5 pm or until a specified time. Due to a leader in Mapalus activities should be an example and demonstrate ability and sense of responsibility. This is usually indicated by very tight working hours, starting from for example $07.00 \mathrm{am}$ and finishing at $5.00 \mathrm{pm}$. Where all those involved in Mapalus activities should go together and go home together as well.

\section{Mutual Assistance Value in Mapalus Culture}

Doing a job together, helping each other, and then enjoying the results of the work together is also the main core of Mapalus culture. The Mapalus culture is still preserved and maintained in the Minahasa community, especially in Tompaso Baru. In Tompaso Baru people feel they are always helped and become more related to one another regardless of ethnicity, religion, race, and intergroup. If there are Mapalus agricultural activities, the community will flock to the plantation area which is still covered with shrubs and large trees, they want to open new plantation land. Usually, the adult men are in charge of clearing shrubs while the remnants of the grass are tidied up by the boys. While the adult women prepare food in tents they set up themselves. The food they prepare will be eaten together at rest during the day. Usually, adult men and women and children get their respective duties Mapalus can run and efficiently.

Based on the results, it is in line with the opinion of reference [17] in the book, The Mapalus Way, which states Mapalus as a working system has ethical values such as, reciprocal ethos, participatory ethos, solidarity, responsibility, cooperation, good leadership, discipline, transparency, equality, and trust. Along with the development of social organization functions implement activities with the Mapalus principle, currently, Mapalus is also often used as the principle of a social organization in Minahasa, for example, Mapalus farmers, Mapalus fishermen, Mapalus mourning and marriage assistance; and Mapalus for certain groups of people.

In its implementation, Mapalus can also function as a deterrent for the economic recession of the community, a means to motivate and mobilize people for the stabilization of development and is a means of fostering a productive work spirit for the success of the agricultural intensification and extensification program. One of the principles of solidarity reflected in Mapalus culture is reflected in the economy of the people of Minahasa, namely the introduction of the Tamber economic principle. The principle of tamber economics refers to an activity to give something to other people, or residents of sewanua (village) voluntarily and for free, without calculating or expecting compensation. The principle of tamber economy is familybased. In terms of traditional motivation, this principle contains a meaning of cultural glue (cultural preservation) which expresses social care, even indicators of social intimacy. The cultural factor of the tamber economic principle is based on the fertile and abundant natural conditions of the Minahasa, and the typical Minahasa people who tend to be diligent and generous.

\section{CONCLUSION}

Based on the results of the research and discussion, it can be concluded several things as follows:

Mapalus is an embodiment or manifestation of the Minahasa people's way of life that is manifested as a system of life management and empowerment of individuals and ancestral heritage people who use it as a principle of family life due to it is a set of behavioral concepts for life and for solving common problems. Initially, Mapalus was conducted specifically on activities related to agriculture, from clearing land to harvesting. But along with the development of Mapalus not only limited to agriculture, but also applied in every social activity, and almost all fields of life, as in other traditional activities, such as marriage, death or establishing a new house and other activities which are done together, or cooperation.

Values contained in Mapalus culture Participatory, wherein Mapalus activities all people are actively involved, starting from the beginning of the plan to conduct Mapalus to completion. In every Mapalus activity, all people who participated in the activity we're involved fully from the planning of the activity to the completion of the activity. The value of Solidarity in Mapalus culture appears a sense of togetherness, a sense of unity of interest, a sense of sympathy, as one member of the same class to jointly conduct Mapalus activities. Reciprocal values in Mapalus culture everyone works together, helping or helping one another.

Therefore, if someone who conducts Mapalus activities for themselves or their families, then when there is Mapalus activity for other people/families, the person concerned should also repay him to work for the family. Leadership Value in Mapalus culture the ability of a leader to recognize the time and need to conduct activities, identify, communicate the implementation strategy / Mapalus activities to everyone involved in these activities for these activities can be achieved. Mutual Cooperation values in Mapalus culture doing a work conducted together, helping each other, then enjoy the results of the work together is also the main core of Mapalus culture.

\section{ACKNOWLEDGMENT}

Special thanks to Dean of Social Science Faculty Manado State Univesity. 


\section{REFERENCES}

[1] T. Pangalila, 'Pengaruh internalisasi nilai budaya Si Tou Timou Tumou Tou, Mapalus dan Torang Samua Basudara Dalam Pembelajaran PKn Terhadap Peningkatan Sikap Toleransi Siswa: Penelitian Survey Terhadap Siswa SMA di Kota Tomohon-Sulawesi Utara', Universitas Pendidikan Indonesia, Bandung, 2013.

[2] M. Tumenggung, 'Beberapa Analisa Perbandingan Mapalus dan Gotong Royong', Majalah Duta Budaya. Manado, Manado, 1971.

[3] Tilaar, 'Mapalus dalam Konteks Pengembangan Manajemen di Indonesia.' Manajemen, Majalah Para Manajemen dan Eksekutif Indonesia, No. 32 Tahun VI. Jan- Feb 1986., Jakarta, 1986.

[4] T. Pangalila, 'Toleransi dalam Keberagaman Masyarakat Lokal: Studi Fenomenologis Hubungan antar Agama dan Etnis pada Masyarakat Kota Tomohon Sulawesi Utara', Universitas Merdeka Malang, 2018.

[5] V. Umbas, 'Mapalus: Gagasan dan Ajaran', 2011. [Online]. Available: http://cahyasiangwilsonlumi.wordpress.com/2011/0 1/13/mapalus-gagasan-ajaran/. [Accessed: 16-Apr2015].

[6] T. Pangalila, B. Ngarawula, and K. Sadhana, 'Tolerance behavior among society in city of Tomohon, North Sulawesi', Int. J. Humanit. Soc. Sci. Res., vol. 4, no. 4, pp. 46-49, 2018.

[7] T. Pangalila, B. Ngarawula, K. Sadhana, A. L. Lonto, and S. Pasandaran, 'Local wisdom si tou timou tumou tou in forming tolerance of Tomohon city people of North Sulawesi', in 1st International Conference on Social Sciences (ICSS 2018), 2018, vol. 226, no. Icss, pp. 811-814.

[8] T. Pangalila, J. Mantiri, and M. Umar, 'The Role of Mapalus Local Wisdom in Building the Tolerant Attitudes of the Tomohon City Community', in 2nd
International Conference on Social Science (ICSS 2019), 2019, vol. 363, no. Icss, pp. 711-714.

[9] T. I. Turang, A. Suman, J. Mandang, and Soemarno, 'Kajian Peran Mapalus dalam Pemberdayaan Masyarakat di Kota Tomohon', Wacana, vol. 15, no. 4, pp. 1-7, 2012.

[10] V. A. Sarajar, H. M. dan Pangkerego, 'Persepsi masyarakat terhadap mapalus di daerah Sulawesi Utara'. Direktorat Sejarah dan Nilai Tradisional, Bagian Proyek Pengkajian dan Pembinaan NilaiNilai Budaya Sulawesi Utara, Manado, 1996.

[11] J. Turang, Profil Kebudayaan Minahasa. Tomohon: Majelis Kebudayaan Minahasa, 1997.

[12] N. S. Kalangi, Kebudayaan Minahasa, dalam Koentjaraningrat, Manusia dan Kebudayaan di Indonesia. Jakarta: Djambatan, 2002.

[13] Koentjaraningrat, Pengantar Ilmu Antropologi. Jakarta: Rineka Cipta, 2002.

[14] S. A. Sembiring and L. Berutu, 'Modal Sosial dalam Komunitas Kuta Etnis Karo dan Relevansinya dengan Otonomi Daerah’. 2004.

[15] L. J. Moleong, Metodologi Penelitian Kualitatif. Bandung: Remaja Rosdakarya, 2011.

[16] M. Najoan, A. Pelealu, and P. Tuerah, 'House Mapalus in Tombatu District; Southeast Minahasa Regency', in 2nd International Conference on Social Science (ICSS 2019), 2019, vol. 383, no. Icss, pp. 639-642.

[17] V. Umbas, 'Dynamic of Mapalus'. Researcher of ICRES, 2011. 